\title{
Chondromyxoid Fibroma of Lumbar Vertebrae: A Case Report
}

\section{Lomber Omurganın Kondromiksoid Fibromu: Olgu Sunumu}

\author{
(1) Densel Araç1, (1) Hüseyin Bozkurt² \\ ${ }^{1}$ Necmettin Erbakan University Meram Faculty of Medicine, Department of Neurosurgery, Konya, Turkey \\ 2University of Health Sciences Turkey, Ankara Kecioren Training and Research Hospital, Clinic of Neurosurgery, Ankara, Turkey
}

Keywords: Chondromyxoid fibroma, lumbar vertebra, MRI

Anahtar Kelimeler: Kondromiksoid fibroma, lomber omurga, MRG

\section{Dear Editor,}

A 56-year-old female was admitted to our clinic with difficulty of walking. She described neither neurologic claudication nor radicular pain. Her symptoms progressively had worsened for the last 6 months. A neurologic examination revealed right Laseque positivity at 30 degrees, right extensor hallucis longus muscle weakness, and right L5 dermatomal hypoesthesia. There was no urinary incontinence. Plain X-ray of lumbar vertebra showed degenerative changes (Figure 1). Magnetic resonance imaging (MRI) scans showed a lesion adherent to the right L4 lamina, T2weighted images showed a high signal lesion with a low signal intensity rim, which was very similar to the neighboring bony structure (Figure 2). In our case, we preferred en block resection and curettage. A soft purple-colored mass under the right L4 laminae pressing the L5 root was substracted and bony margins were curated. Histopathologic diagnosis was confirmed as chondromyxoid fibroma. The patient was followed for 6 months with full recovery of sensory and motor symptoms and with no recurrence.

Chondromyxoid fibroma is a benign tumor of long bone metaphysis-derived from cartilage precursor elements (1). Spinal involvement is extremely rare. Conventional radiographs show a well-marginated, expansile, lucent, eccentric, medullary lesion (2). Lesion margins usually appear sclerotic and rarely contain visible calcification (3). Computed tomography provides more detailed information about chondromyxoid fibroma; scans display a sclerotic calcification margin and trabeculation better than conventional radiography (4). The MRI features of chondromyxoid fibroma of the vertebral column are a peripheral intermediate signal

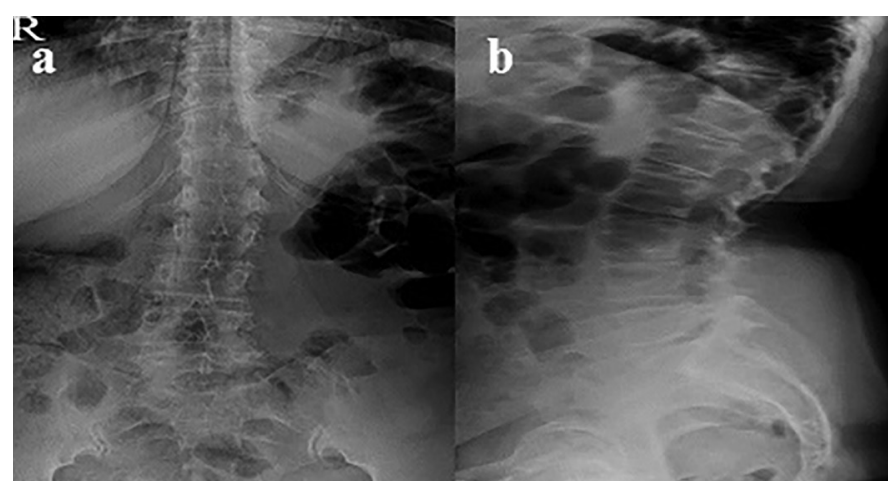

Figure 1. Plain X-ray revealed no significant indication of chondromyxoid fibroma because of adherent structures and superposition of multiple layers $(\mathrm{a}, \mathrm{b})$

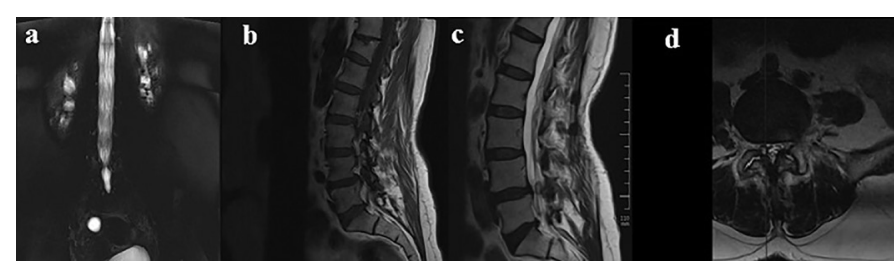

Figure 2. Magnetic resonance myelogram showed cerebrospinal fluid flow obstruction on L4-5 disc space (a). T1-weighted images showed low signal intensity lesion adherent to right L4 lamina and foraminal stenosis (b). T2-weighted images showed a high signal lesion with a low signal intensity rim, very similar to neighboring bony structure (c, d)

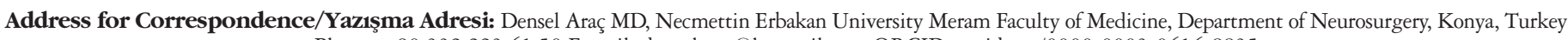
Phone: +90 3322236150 E-mail: denselarac@hotmail.com ORCID: orcid.org/0000-0003-0616-8835 Received/Geliş Tarihi: 08.07.2019 Accepted/Kabul Tarihi: 07.01.2021

${ }^{\circ}$ Copyright 2021 by Turkish Neurological Society

Turkish Journal of Neurology published by Galenos Publishing House. 
band, central high signal intensity on T2-weighted images, and peripheral nodular enhancement or central non-enhancing focus on contrast-enhanced T1-weighted images (5). Surgical resection has been the mainstay of treatment for spinal chondromyxoid fibroma because malignant transformation is possible, thus radical removal is the treatment of choice.

\section{Ethics}

Informed Consent: Patient's consent was received.

Peer-review: Externally and internally peer-reviewed.

\section{Authorship Contributions}

Surgical and Medical Practices: D.A., Concept: D.A. Design: D.A., Data Collection or Processing: H.B., Analysis or Interpretation: D.A., Literature Search: H.B., Writing: D.A., H.B.

Conflict of Interest: No conflict of interest was declared by the authors.
Financial Disclosure: The authors declared that this study received no financial support.

\section{References}

1. Lopez-Ben R, Siegal GP, Hadley MN. Chondromyxoid fibroma of the cervical spine: case report. Neurosurgery 2002;50:409-411.

2. Vigorita VJ. Orthopedic pathology in cartilage tumors. 3rd ed. Kluver Philedelphia: Wolters; 2016:427-488.

3. Granter SR, Renshaw AA, Kozakewich HP, Fletcher JA. The pericentromeric inversion, inv(6)(p25q13), is a novel diagnostic marker in chondromyxoid fibroma. Mod Pathol 1998;11:1071-1074.

4. Wilson AJ, Kyriakos M, Ackerman LV. Chondromyxoid fibroma: radiographic appearance in 38 cases and in a review of the literature. Radiology 1991;179:513-518.

5. Kim HS, Jee WH, Ryu KNet al. MRI of chondromyxoid fibroma. Acta Radiol 2011;52:875-880 